\title{
Implementing lesson plans for collaborative learning with children in an EFL context ${ }^{1}$
}

Implementación de planes de clase para el aprendizaje colaborativo con niños y niñas en un contexto de inglés como lengua extranjera

\author{
Daisy Catalina Carvajal-Ayala \\ and Ricardo Alonso Avendaño-Franco ${ }^{2 *}$
}

Universidad EAFIT, Colombia

${ }^{1}$ Received: July 13th 2021/ Accepted: May 21st 2021

2 dcarvaj4@eafit.edu.co; ravenda1@eafit.edu.co 


\section{Abstract}

In this article, we describe a case study research conducted to validate a set of lesson plans specifically designed for collaborative work with children. A group of nine teachers implemented the lessons in their classes. Data were gathered by means of ethnographical notes to determine children's reactions to collaborative work. Class observations and surveys to teachers on their perception of the lesson plans and collaborative learning were used to collect the data. Results show that children can indeed work in collaboration when given the adequate conditions. This kind of work among children helps them to negotiate meanings and find solutions for learning spaces. Implications point in the direction of teacher education programs that can help teachers understand the principles and practices of collaborative learning with children.

Key words: collaborative work; collaborative room; interaction; technology-supported input; negotiation in children; collaborative learning spaces; children's reaction to collaboration

\section{Resumen}

Diferentes autores han argumentado que el trabajo colaborativo entre los niños les ayuda a negociar significados y a encontrar soluciones para el aprendizaje. En este artículo, describimos un estudio realizado para validar un conjunto de planes de lecciones diseñados específicamente para el trabajo colaborativo con niños en espacios de aprendizaje colaborativo. Un grupo de nueve maestros implementó las lecciones en sus clases. Los datos se recopilaron mediante notas etnográficas para determinar las reacciones de los niños al trabajo colaborativo. Además, los maestros respondieron un cuestionario sobre su percepción de los planes de lecciones y el aprendizaje colaborativo. Los resultados muestran que los niños pueden trabajar en colaboración cuando se les dan las condiciones adecuadas. Las implicaciones apuntan en la dirección de los programas de educación docente que pueden ayudarlos a comprender los principios y prácticas del aprendizaje colaborativo con los niños.

Palabras clave: trabajo colaborativo; sala colaborativa; interacción; input respaldado por tecnología; negociación en niños; espacios de aprendizaje colaborativos; reacción de los niños a la colaboración 


\section{Resumo}

Diferentes autores têm argumentado que o trabalho colaborativo entre as crianças ajuda-os a negociar significados e a encontrar soluções para a aprendizagem. Neste artigo, descrevemos um estudo realizado para validar um conjunto de planos de lições desenhados especificamente para o trabalho colaborativo com crianças em espaços de aprendizagem colaborativo. Um grupo de nove professores implementaram as lições em suas aulas. Os dados se recopilaram mediante notas etnográficas para determinar as reações das crianças ao trabalho colaborativo. Além disso, os professores responderam um questionário sobre a sua percepção de dos planos de lições e a aprendizagem colaborativa. Os resultados mostram que as crianças podem trabalhar em colaboração quando se lhes dão as condições adequadas. As implicações apontam na direção dos programas de educação docente que podem ajudá-los a compreender os princípios e práticas da aprendizagem colaborativa com as crianças.

Palavras chave: Trabalho colaborativo; sala colaborativa; interação; input apoiado por tecnologia; trabalho colaborativo em crianças; aprendizagem colaborativa; negociação nas crianças; espaços de aprendizagem colaborativa; reação das crianças à colaboração 


\section{Introduction}

$\mathrm{n}$ recent years, interest in researching methodologies or techniques to improve learning in the classrooms has increased, giving way to collaborative work, which is one of the latest learning techniques that emerges from the communicative approach to language teaching (Gjergo \& Samarxhiu, 2011). Collaborative learning is a situation where one or more students learn or try to learn something together. In this sense, the traditional teacher-student relationship is redefined to allow groups of students to work together to seek understanding, meaning, or solutions for learning. Jacobs, Power and Loh (2002) define collaborative learning as the principles and techniques for helping students work together more effectively.

Working in collaboration with others brings different advantages for children. First, the ideas and opinions of peers stimulate children's response since they are exposed to the individual perceptions that others may have of a problem or a situation. These perceptions reflect:

the different personalities and particular abilities of other members of the group make for an interactive exchange that will help to broaden and deepen individual children's understanding. Moreover, the experience of collaborative learning facilitates the child's social and personal development, and the practice of working with others brings children to an early appreciation of the benefits to be gained from co-operative effort. (The stationery office of Dublin, 1999, p. $17)$.

Connected to the beforementioned idea about the possible benefits of collaborative children's learning, Barkley, Major, and Cross (2014) also pointed out three qualities that characterize collaborative learning. They initially considered that collaborative learning tasks should be organized systematically; that is, rather than having learners get together to work, collaborative activities need to have a useful purpose. An additional element they referred to is that each participant is required to take part and contribute to the activities planned. Finally, Barkley et. al. put forward the fact that collaborative learning needs to be meaningful to facilitate and support the achievement of the learning objectives.

Given the advantages of collaborative learning, we set out to investigate the usefulness and benefits of different lesson plans specifically designed for the small group collaborative learning rooms at Idiomas Eafit. The institution counts with five collaborative spaces that have been somewhat neglected due to teachers' lack of knowledge and experience in using such spaces and in techniques to foster collaboration among students. Three spaces function as small group collaboration rooms, another as the crafts room, and the other as the pedagogical kitchen. 
The layout of the small group collaboration rooms highlights group learning. The rooms count with three large group tables fixed to the floor with moveable seating (rolling chairs) designed to aid and encourage collaborative work. Each table is accompanied by a laptop with access to the Internet and a flat screen monitor to display content and student work. Monitors also offer surrounded sound. There is also a whiteboard wall that covers most of the room and that allows teachers to write $360^{\circ}$ information. The acoustics of the space offers a free-noise environment (see Figure 1).

The crafts room presents opportunities to students for developing varied artistic interests. It is equipped with a screen monitor and a laptop with access to the Internet. As in the collaborative room, there is a whiteboard wall wrapping most of the area. The room also contains a variety of chairs and trapezoid tables on casters aimed at facilitating movement and fostering different grouping techniques. To keep material, the room offers an art supply storage closet (see Figure 2).

Figure 1. Small Group Collaboration Room (own photo)

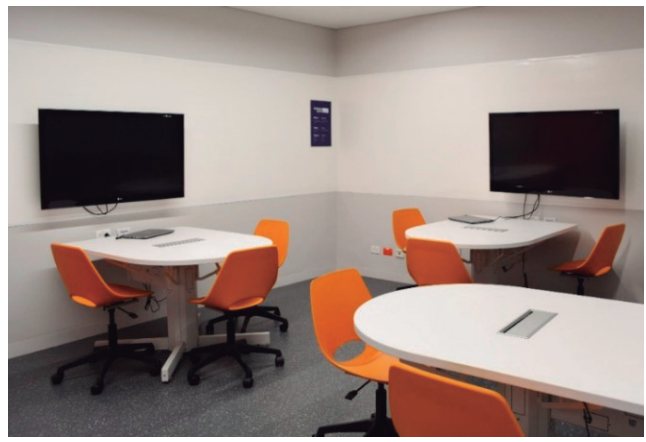

Figure 2. Crafts Room (own photo)

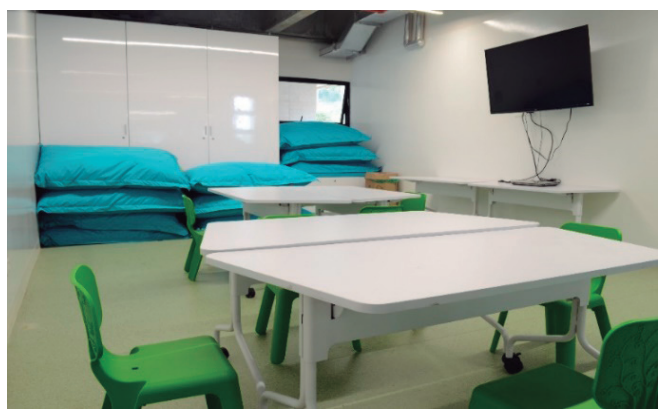


The pedagogical kitchen is an area intended to offer authentic material for the teaching and learning different foreign languages. It aims at developing the learners' cultural and communicative competences by engaging them in an experiential context that involves a real-world situation as the act of cooking. The kitchen is furnished with storage cabinets, open shelves, a counter, a sink, and an island located in the middle of the space with high stools around it. It is equipped with a refrigerator, a microwave, an oven, a digital stove fitted in the island, varied appliances and a wide selection of kitchen tools. The space also counts with a screen monitor, Internet connection, and a whiteboard wall (Figure 3).

Figure 3. Pedagogical Kitchen (own photo)

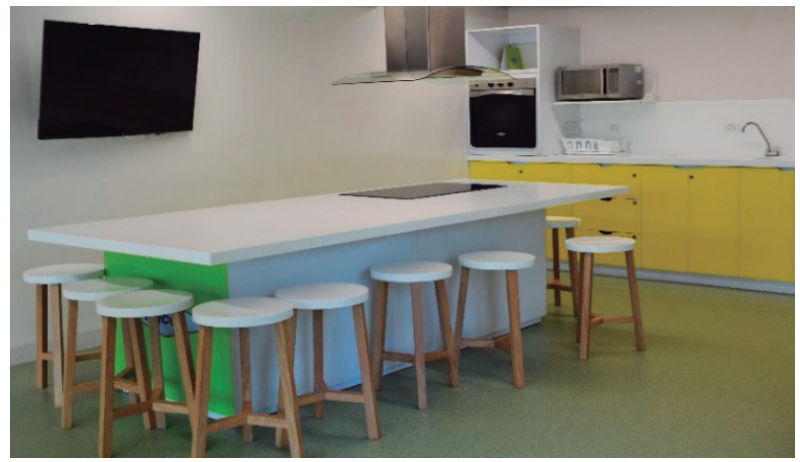

The difference between a traditional classroom and a collaborative room can be established as follows: In a traditional classroom, all desks are either facing the board and the teacher's desk or arranged in a semi-circle. Both layouts promote teachercentered classes since they encourage focus on the instructor, the content, and they can be implemented with large groups without any difficulties. For instance, a seating arrangement in rows may be chosen to improve information dissemination, whereas an arrangement in small groups, as in a collaborative room, may be chosen to promote student interactions (McCorskey \& McVetta, 1978 cited in Gremmen et al., 2016).

The disadvantage of a row arrangement is that the teacher is distant from the students sitting in the last rows. This population is more likely to be distracted and lose attention. As a result, disengagement is expected to happen. In a language lesson where conversation and interaction enable learners to put into practice communicative needs, a traditional classroom design makes it hard for the instructor to move around the audience, participation seems to decrease and group involvement fosters oneway interaction (Brown \& Long, 2006). In contrast, the seating arrangement in a collaborative room fosters the flow of oral interactions since students are most likely to interact with each other in a more fluent way, and they are also most likely to improve 
their language skills, specially speaking (Harmer, 2007). Therefore, the dynamics of a language class, the learning objectives and the characteristics of the population match the design of collaborative rooms.

The evolution of the classroom from a fixed physical space into a dynamic learning environment has been possible thanks to changes in teaching methods and new understandings of learning strategies and styles. This fact draws attention to the concept of the collaborative classroom. Nilsson (2016) states "the design of the collaborative classroom emphasizes group learning" (p.3). Typically, tables enable small groups to sit and work together, unlike the rows of desks associated with factory model schools of last century. Each group has ready access to the Internet, multimedia displays and collaboration software. The group tables, shared table-top displays, and wall displays with unrestricted lines of view, are the most common characteristics of the collaborative classroom. Han, Leong and Nair (2014) also elaborate on the advantages of the collaborative learning environment stating that

Interactive classroom technologies provide an ideal learning environment for students and provide support for alternative learning paradigms. Facilitators are able to use technology as a tool or vehicle to engage students and to improve the quality of learning. Thus, there is a clear educational rationale to justify the development of interactivity tools and technology-rich learning spaces. (p. 274).

Based on the characteristics of collaborative rooms, the main objective of the work presented in this article is to validate a set of lesson plans designed to foster collaboration among children aged 5 and 8 who were enrolled in courses 1A, 2A, $1 \mathrm{~B}$ and $2 \mathrm{~B}$ of the English program for children at Idiomas Eafit. This program falls within the definition of teaching English as a foreign language and is framed under the communicative approach. The methodology privileges the active and creative participation in meaningful, playful, and authentic communicative activities among the actors of the process: participants, parents, teachers, people of the community, etc. The tools to implement this methodology are audiovisual materials (posters, audio, video, games, texts, etc.) and educational technology such as the computer laboratory and educational online platforms. The programs are designed taking into consideration the age, cognitive development, and proficiency level of each participant in the target language.

\section{Literature Review}

Learning is a social activity that involves language, real world situations, interaction and collaboration among learners (Bawa \& Suleiman, 2015). These authors claimed that collaborative learning is a process of peer interaction that is mediated 
and structured by the teacher. Collaboration thus implies that both the learner and the teacher contribute and take insights out of the class encounter. The more they communicate, the more they create knowledge using language in a social context.

Collaborative learning has been defined in different ways. For instance, Swain (2000, cited in dos Santos Lima, 2011) defined the notion of collaborative dialogue as the act where the participants are involved in knowledge construction and problem solution through means of creating relations and exchanging ideas. The author argued that while collectively working towards a common goal, individuals are able to establish meaningful connections which draw them to understand each other and find ways to solve problems.

Dillenbourg (1999) described collaborative learning as a "situation in which two or more people learn or attempt to learn something together" (p. 1), In his definition, two or more people can range from a pair or a small group with three to five learners until a community of thousands or millions of people. To learn is understood as the act of attending a course, studying the teaching materials, participating in the learning activities, or the gradual gathering of lifelong experiences. Together connotes various types of interaction, such as face-to-face interaction, interaction mediated by computer, whether or not it is a shared accomplishment, and if the work is organized in a systematic way.

Another definition of collaborative learning is provided by Gokhale (1995) who defined it as a method of instruction where two or more students of different performance levels come together to work on a shared objective. They are in charge of both their learning and their peers' progress. Therefore, collaborative learning activities help the success of each other. According to Song (2011) collaborative learning is a kind of learning style carried out in a group where participants are able to solve problems and gain understanding through "consultation, discussion, and competition." A typical collaborative learning process, states Song, values interaction as a major source of learning activities since efforts between learners and instructors encourage reciprocal progress. Additionally, learners create a group structure that leads them to the achievement of a common goal. Another circumstance adding to the collaborative process draws attention to the learner's own responsibility in front of the working tasks. Finally, a group target must be reached so that the collaborative learning can be ended; that is, all group members have attained the goal.

Collaborative learning as concerned with younger students had its roots in ideas of socio-cognitive conflict (Doise \& Mugny, 1984; Piaget, 1932, 1985). This view posits that disagreement with one or several peers over a task that involves learning could encourage intellectual activity and ensue progress (Azmitia, 2000; Clark et al. 2003; Howe \& Tolmie, 1998). That is, children are able to acquire knowledge throughout their social interactions with a person of the same age. 
According to Tunnard and Sharp (2009), collaborative learning occurs when children work together to achieve a common goal or to solve a problem. The authors reported that many quantitative studies of learning behaviors and outcomes have indicated that collaboration between peers can help children to develop their knowledge, language, and social skills. The authors also conducted a study of children's views of collaborative learning in a sample of 16 children (eight boys and eight girls), year $5 / 6$, where the use of collaborative learning across the curriculum with the daily use of team-orientated tasks was actively promoted. The findings revealed that several children held that collaboration facilitated their comprehension of new ideas even though they did not give their best to work in groups. Besides, children favored selfselection as a process for determining group composition. Some of the children also valued the importance of individual skills for collaboration and they believed that social skills were linked to personality. As a final point, children stressed the view of working together as an important way to establish and maintain friendships.

To summarize thus far, collaborative learning is one of the teaching methods where learners work together to understand a concept, develop a product, or solve a problem. Group members take part to ask for information, assess ideas, and keep track of their work in collaboration. Even though performing a joint effort, each member is responsible for and accountable to each other. Collaborative learning can either follow the form of face-to-face communication or make use of computer-assisted platforms. It fosters a context where members collaborate by sharing experiences and taking on different roles. Thus, collaborative learning holds social, academic, and psychological advantages.

Collaborative learning requires teachers and students to play characteristic roles. As far as teachers are concerned, Larrañaga (2012) and Gokhale (1995) asserted that instructors need to stay away from the traditional knowledge transmission model who passes on information. Instead, teachers need to function as mediators for learning or managers of tasks (Smith \& MacGregor, 1992; Gerlach, 1994) by fostering significant learning experiences that might connect learners to the real world (Mukkonen, Lakkala, \& Hakkarainen, 2005 cited in Larrañaga, 2012).

Collazos, Guerrero, and Vergara (2001) affirmed that teachers should take three different roles: instruction designer, cognitive mediator, and instructor. According to these authors, the teacher as an instructor designer is in charge of creating interesting learning contexts and tasks that help learners associate new with stored information. The cognitive mediator is responsible for asking questions that seek to verify learners' understanding. The instructor is in control of monitoring, intervening, coaching, evaluating, giving instructions and explaining the structure of the collaborative work and the social abilities related to it.

Regarding the students' role, Larrañaga (2012) contended that a collaborative approach engages learners in a situation of responsibility for their own learning. 
In other words, learners need to recognize the value of their capacities to guide their thoughts and behaviors to reach goals and solve problems within the team. They establish the learning objectives and decide on the importance of particular problems. In this new role, students also benefit from a strong network of group support and direction where they learn from peers more than they do from teachers (Santamaria, 2005). Additionally, McInnerney and Roberts (2003), asserted that each student is viewed individually even though working in collaboration. If they hand in an assignment, for instance, "they present themselves, not the small group they work in" (Holm, 2018, p. 19).

With reference to the role of technology, Domalewska (2014) suggests that collaborative learning is founded in a structure of group dynamics where learners make part of a social learning environment. In this context, technology is a strategic factor in creating both effective lessons and collaborative work settings. The author argued that Web 2.0 tools and devices such as laptops and screens allow the learners and the teachers to connect with each other and to facilitate the flow of information, interaction, and negotiation of meaning. She adds that technology-supported input channels learners to improve both their social and academic skills and obtain new knowledge.

\section{Potential Problems of Collaborative Work}

A variety of external factors or elements impact collaborative learning and these could affect the success or failure in the learning process. Saez (2010) described eight categories that can cause the failure of the process: lack of teaching the principles of collaboration, lack of experience and previous knowledge, lack of training teachers and students in collaborative learning, no organized planning or presentation of tasks, lack of commitment and dedication, technological problems, problems of understanding role change, and lack of experiencing social presence in collaborative learning.

The size of the group can also affect the success of collaboration. For this reason, smaller group size is beneficial to achieve collaboration (Dishon \& O'Leary, 1998). The authors claim that students' age and experience of working in groups, the nature of the learning activity, the time available, and the materials will all influence the size of the group. They also argue that students should work in pairs until they are good at working together. As they gain in experience, the children should experience working in threes (triads) and later in fours and perhaps fives. 


\section{Research Design}

To address the central objective of this study (validate lesson plans based on activities for collaborative learning environments), we collected and analyzed data following a Case Study methodology. This type of research design was appropriate because it has as main objectives to present the outcomes of a particular context by conducting an in-depth exploration of the case in a specific context and to build awareness of the technical and methodological experiences (Meyers, 2004). Nine teachers (two males and seven females) from the English program for children participated in the study.

Knowing the characteristics of the case study methodology and aiming to design lesson plans for collaborative classrooms and explore teachers and students' reactions towards collaborative learning activities, we followed the following process to get the data and analyze it (see figure 4):

Figure 4. Process designing, collecting, and analyzing data

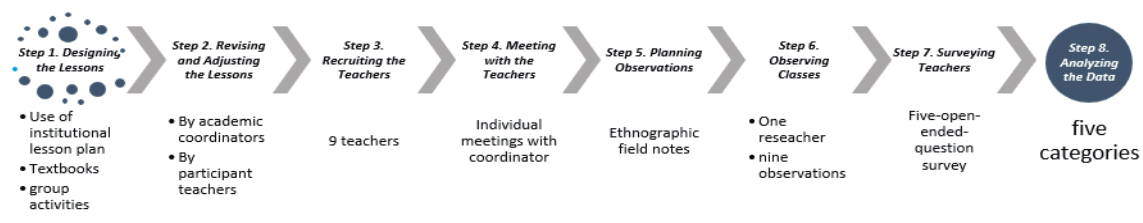

\section{Procedures}

\section{Step 1. Designing the Lessons}

The lesson plans were designed based on the contents students had previously worked on in their textbooks. The lessons were designed following the institutional lesson plan form which contains seven stages of class development: Warm-up, Engage, Explore, Construct, Practice, Extend, and Wrap-up. These phases are based on the philosophical principles of the cognitivist psychology and social constructivism and they follow the communicative approach to language teaching.

All the activities included in each phase of the lesson plan were meant as a review. Thus, the plan was to be carried out the class following a unit of work. The activities included songs, videos, puzzles, PowerPoint displays and games, worksheets, easy-to-make crafts, online games, and use of realia. The strategies of collaborative work contained in the lessons were: Turn-taking; sharing work; presenting work to classmates; and completing a task together (e.g. building puzzles together). 
It is important to note that the lessons seldom consisted solely of group activities since collaborative learning combines well with other modes of learning, such as lecture by the teacher and individual work.

\section{Step 2. Revising and Adjusting the Lessons}

Once the teacher researcher designed the lessons, revisions and adjustments were suggested by one of the academic coordinators and by the participant teachers.

\section{Step 3. Recruiting the Teachers}

Nine teachers (two males and seven females) from the English program for children participated in the study. Before the class, teachers were sent the lesson plan and were asked to read it. They were also asked to stop by the academic coordinator's office to discuss any doubts or questions they may have had and to collect the required materials for the lesson. All teachers were selected having into account their teaching experience (at least 5 years teaching children), years of being part of the institution (3 or more years) and their background (all of them had a bachelors 'degree in teaching). Teachers were asked to sign a consent form as part of the ethical considerations of the research.

\section{Step 4. Meeting with the Teachers}

The program coordinator met with individual teachers to discuss any doubts or questions about the lesson. The teachers were instructed to follow the lesson, as closely as possible.

\section{Step 5. Planning Observations}

The researchers discussed the most suitable method to collect information via observations. Decisions were made about carrying out ethnographic field notes because this method could provide meaningful information about the complexity of group behaviors, show interrelationships among group interactions, and provide context for the observed behaviors. 


\section{Step 6. Observing Classes}

One of the researchers, skilled in note taking, conducted nine observations. The notes contained a narrative of all the events in the lesson, including specific facts, details of what happened during the class, impressions, specific words or phrases, and summaries of teachers and children's conversations.

\section{Step 7. Surveying Teachers}

Teachers were asked to complete a five-open-ended-question survey in which we inquired about the effectiveness and difficulties of implementing the lesson plan for the collaborative learning spaces. (see Results section)

\section{Step 8. Analyzing the Data}

Data from observations were analyzed qualitatively by identifying, grouping, and categorizing the observations that pointed in similar directions (Marshall \& Rossman, 2016; Rubin \& Rubin, 1995). The resulting categories were: 1) children's reactions to the collaborative room \& to the activities; 2 ) children's reactions to collaborative work; 3) teacher encouragement of collaborative work; 4) teacher's implementation of the lesson plan; and 5) equipment functioning. All the answers given by teachers to the survey were grouped and summarized by number of question and are presented in the Results section below.

\section{Results}

We carried out a qualitative analysis of the notes from the observation and the surveys, created categories by grouping the information that pointed at similar directions. Then we now present the results divided in five categories.

\section{Children's Reactions to the Collaborative Rooms \& Activities}

From the observer's notes, it can be seen that moving to a non-traditional space generated expressions of curiosity, agitation, and, sometimes, misbehavior. Along the nine observations, children had physical responses such as: touching the equipment on the tables; playing on and with the rolling chairs; following instructions lively and 
noisily; not listening or following instructions; manipulating the software, closing the window of the link, making it bigger, smaller; watching the videos attentively; playing with the worksheets; threatening each other; or helping the teacher arrange the furniture.

There were also verbal expressions about the rooms:

- $\quad$ No me gusta el salón [I don't like this classroom $]^{3}$

- ¿ ¿Por qué tantos televisores? [Why are there so many TV sets?]

- Estas sillas son más cómodas que las del salón [These chairs are more comfortable than the ones in our classroom]

Regarding reactions to the activities, there were overall acceptance, engagement, and enjoyment as demonstrated by children's active listening and participation, eagerly dancing or jumping around when prompted by the teacher, or taking notes about the instructions the teacher gave, or showing enchantment and surprise (some children said "wow" and covered their mouths as an indication of wonder when the teacher played a video they really liked), or asking the teacher to repeat the activity, or checking for understanding of the instructions, or looking at the teacher's demonstrations attentively and following instructions.

- Some of the positive comments provided by children about the activities were:

¡Estamos más pilosos con este juego que que! [We’re doing so well with this game!]

- Yo quiero hacerlo otra vez [I want to do this activity again]

- ¡Qué lindo! [How beautiful!]

There were also some negative comments about the activities such as:

- $\quad$ Esto si es difícil [This is so hard]

- ¿Cuándo vamos a ver tareas en los libros? [When are we going to work with the textbook?]

${ }^{3}$ Comments translated to English by the authors. 


\section{Children's Reactions to Collaborative Work}

Within this category, we included the strategies: Turn taking, sharing work and opinions, presenting work to classmates, and completing a task together.

\section{Turn-taking}

Children seemed to understand the concept of turn taking as evidenced by children standing and letting other classmates use the computer or by effectively taking turns when completing exercises, answering questions, or helping each other

\section{Sharing Work and Opinions}

Some of the behaviors for this strategy as described in the field notes were:

- $\quad$ Sharing pictures distributed by the teacher

- $\quad$ Sharing finished work with their teachers or classmates

- $\quad$ Sharing material and helping each other

- Giving recommendations to each other ("Esas muñequitas son para aprender" / "those dolls are for learning." $)^{4}$

- $\quad$ Exchanging materials

- $\quad$ Giving opinions about each other's work

- $\quad$ Sharing opinions on decoration or foods they like:

- ¿A usted le gustan los frijoles, las zanahorias? [Do you like beans? Carrots?

- A mí me gusta la leche en polvo. [I like milk powder]

- A mí me gustan los dulces. [I like candy]

${ }^{4}$ A child's response to another child who criticized the dolls. 


\section{Presenting Work to Classmates}

One of the activities suggested that children presented their work to a host class. The reactions coded by the observer when the children returned to their own classroom and the teacher asked them how they felt were:

¡Bien!

¡Bien, gracias a Dios!

Very good!

Yo creí que eran grandes y son chiquitos.

Me sentía más feliz.

Me sentí happy.

Nerviosa.

Happy!

Casi que me pongo a llorar.
[Good!]

[Good, thanks God!]

[Very good]

[I thought those students were older, but they are younger]

[I was so happy]

[I was happy]

[nervous]

[Happy]

[I was about to cry.]

\section{Completing a Task Together}

The notes show that even though, at the beginning of the classes, children had difficulties working together because, they ended up helping each other, participating enthusiastically, and enjoying the tasks. Common behaviors observed from children were: offering help to another student, putting pieces together to complete a puzzle, celebrating when they found a match, and checking boxes in a worksheet together.

\section{Teacher Encouragement of Collaborative Work}

The following are specific actions done by the teachers to prepare children for collaborative work:

- Announce to the class they will have some special activities

- Use L1 to emphasize the need to share material

- Number children so that they can take turns coming to the board

- Encourage children to reach consensus on a decision to be made 
- Encourage children to play the game in their laptops, taking turns

- Model how to do a presentation

- Invite students to deliver presentations and encourage others to listen

- $\quad$ Directly assign small group work

- Visit individual tables to repeat instructions

- $\quad$ Praise student work

- Use rewards to persuade children to do a presentation

\section{Teacher's Implementation of the Lesson Plan}

The observations for this category distinguished two different working styles. In some classes, several teachers did not completely follow the lesson plans as designed. For instance, one of the lessons was to be developed in the crafts room and the teacher used the collaborative room. In another class, an activity was to be conducted using a PowerPoint presentation and the teacher did not use it and neither did the materials. In another session, instructions, as indicated in the plan were not followed and the activities proposed for different stages in the lesson plan were omitted.

It was as well noticed that the quality of instructions given was rather poor when teachers made use of translation in order to convey meaning. An indication of this was children looking confused, asking in L1 for confirmation or starting to work on a task different from the one given by the teacher.

On the other hand, some teachers did follow the lesson plan as designed. One teacher had the printed lesson plan and constantly looked at it to see what was next. Another teacher followed the exercises as described in the lesson plan. Further, another teacher, referred to her smart phone to check the order and description of tasks.

\section{Equipment functioning}

The observations revealed a host of difficulties when using the equipment in the rooms. For instance:

- $\quad$ The cd unit did not work properly

- $\quad$ The computer did not have a CD unit

- The PowerPoint was not ready in the laptops or did not have sound 
- $\quad$ Online mirror link did not work properly

- Having equipment ready took longer than expected

- $\quad$ Some children had trouble using the touchpad

- Computer equipment and sound were not working

- Television does not have surround sound.

- laptops without mice (hard for children).

- $\quad$ T also says that chairs do not fit children's conditions. (Furniture)

\section{Teachers Opinions about the Lesson Plans for Collaborative Classrooms}

In this section, we present the answers given by teachers to the open-ended survey.

\section{Q1 What did you like about this lesson plan?}

Some teachers considered that the lesson plans (LP) included songs that fostered student participation, interest, and enjoyment. In addition, the majority of teachers valued the use of videos, mostly because they were short, entertaining, and directly related to the topics. "The connection between topics, activities and the content of videos, helps students memorize and learn more easily," as expressed by one of the teachers. Moreover, the teachers commented that the videos allow children to be more exposed to and interact with the language.

\section{Q2 What difficulties did you encounter teaching this lesson?}

The majority of difficulties encountered by some of the teachers when implementing the lessons was the use of computers. More specifically, they mentioned having technical problems with the Internet connection which failed in many occasions.

Another difficulty, as expressed by one teacher, was that the time suggested in the LP format was not enough because it took him longer to complete the activities. In relation to time, other teachers commented that they needed more time to run all the logistics involved in the preparation of the lesson (video, slides, materials, etc.). For other teachers, difficulties arose due to the lack of material (yarn, plates). Two teachers reported having some trouble with the classrooms themselves. Children were distracted because of "the special classroom." One of the teachers said that since the routine changed students kept asking when they were going to use the textbooks. 


\section{Q3 What would you change in this LP?}

Teachers responded:

- The amount of participants. The collaborative room should only be for small groups maximum 12 students.

- $\quad$ Use less childish material

- Include more content, sometimes the lesson is repetitive; it's review.

- Omit the presentation or visit children do to another classroom (it's intimidating)

- $\quad$ Assign more time per activity.

- $\quad$ Add a computer for each student.

\section{Q4 Do you think the activities proposed foster collaborative work among children?}

Teachers in general think the lessons fostered collaboration. First, the activities were suitable for students working well together. Second, the activities promoted student discussion and decision-making. Third, students had the opportunity to share their knowledge and compare ideas. However, one teacher believes that the students are not mature enough to work collaboratively and another teacher said that the lesson did not encourage collaboration, because in order to foster collaboration children needed to "work on something to present as a group"

Some of the specific responses provided by teachers were:

- Yes, definitely. For instance, when they were marking the boxes according to the information given in the video, they discussed with each other what would the right answers be; and in the "parade»-as the animals were repeated - children would instinctively pair up with those that had the same animals that they did.

- Yes, specially the one related with arts and crafts because they get to share and compare their knowledge and material with their classmates.

- Talking about a subject in common helped them to do the activity in an efficient way with each other.

- No, because they are not mature enough to understand how to work in groups.

Q5 What do you think about the materials? Are they appropriate to the population age and the lesson needs?

Some of the responses were: 
- $\quad$ Yes, but they need to be available

- Yes, the material works and promotes enthusiasm. The material is fun.

- $\quad$ Children were excited to choose the animal they liked

- $\quad$ Yes, the material was perfect

- $\quad$ Some material is childish.

\section{Discussion}

In general, children showed the ability to work in collaboration with each other and interact among themselves. Being exposed to a non-conventional room generated, mostly, positive expressions and behaviors in children. Students displayed curiosity, enthusiasm, and engagement. Even though some of the children exhibited unfavorable attitudes towards the operation of the equipment and some furniture, they were, by no means, resistant to the materials and to the new technological spaces. These technology-rich learning spaces helped teachers in the development and improvement of quality learning (Han, Leong, \& Nair, 2014).

Undoubtedly, teachers must confront challenges while working on collaborative activities such as monitoring students' behavior. In our study, we observed some instances of misbehavior, such as intensively touching the equipment on the tables; playing on and with the rolling chairs; not listening or following instructions; manipulating the software out of time; playing with the materials; threatening each other. Those behaviors may be due to the excitement of being in a new space and the curiosity it generates. It becomes a key point, then, to look for strategies that introduce children to the collaborative room itself. As an example, teachers could walk children to the collaborative classroom on a short, guided tour while explaining what it is, the benefits it could convey for their learning process, and the guidelines for working in this space. Determining the group norms needs to be part of the organization of collaborative activities (Janssen \& Wubbels, 2018). Teachers could also explore the possibility of using multimedia tools as video and images which may well become a means of understanding the aim of moving into a different physical space.

There was a positive reply to complete the activities proposed in the LP when children had a sense of assimilation of the steps they had to follow through. Activities were relevant once the teacher encouraged the class, monitored group work, and repeated instructions when children showed little understanding. Teachers' modeling, for instance, supported by body gestures and contact with the materials needed for each activity, offered children a sequence of connected visuals. In other words, the teacher, 
as described by Collazos, Guerrero, and Vergara (2001), was mirrored along most of the class encounters. Consequently, children were able to take turns effectively, share materials and opinions, present work before classmates, and complete tasks together. In fact, children enjoyed working together toward a same goal, such as completing a puzzle together or helping each other.

On the other hand, activities were unsatisfactory when the instructions were not understood by the children and they followed a different course of action; group work was not fostered having children worked individually, and materials were not completely prepared to be used in each exercise. Herein, the teacher as a cognitive mediator (Collazos, Guerrero, \& Vergara, 2001) fell short in his/her responsibility for asking questions that sought to verify learners' understanding.

Some specific actions were brought by teachers in relation to the encouragement of collaborative work so that children could better internalize the value of working well with others. Some teachers, for instance, built in opportunities for discussion and consensus. They encouraged children to reach agreement on a decision to be made while collaborating. Other teachers praised student work. That little push to collaborate with others was an incentive that helped children become comfortable working with others or in front of others. Some other teachers promoted collaboration by encouraging kids to take turns so they could attain a common goal in their team. Teachers ensured that children were able to share an intellectual space by learning, doing, and experiencing more together than they would alone. With the aim of encouraging collaborative work, another group of teachers demonstrated how to complete a collaborative task before the class, and they attempted to make children involved in collaborative work by reexamining comprehension of activity instructions in each group work.

In relation to the implementation of the lesson plans, some teachers disregarded the instructions given. It is possible that those teachers decided to rely on their own pedagogical and instructional choices to make up for a particular circumstance that arose unexpectedly. It could also be necessary to direct further examination on the process of writing the LP in order to discover underlying obstacles. However, the majority of teachers applied the lessons as they were designed using reminders such as cards or the cellphone. Based on these findings, it is important to consider better teacher guidance through in-service programs where teachers can clearly understand the concept of collaboration among children and the strategies that they can use. Simply following a lesson plan, even if as closely as possible is not sufficient.

As Hafner \& Miller (2011) and Domalewska (2014) suggested, technology has proved to be a strategic factor in creating both effective lessons and collaborative work contexts. These improvements involve the use of videos, platforms, and the Internet, not only to stimulate and persuade students, but also to provide learners with up-todate and authentic material. In this study, teachers found convenient the use of Web 
2.0 tools and devices such as laptops and T.V. screens. Indeed, teachers suggested that technology-supported input like videos and songs helped children to participate, be interested, and enjoy themselves. In addition, teachers considered that the videos and songs presented in most of the lessons were precise, concise, and targeted the subject matter. Also, some teachers assured that videos allowed participants to be in contact and, therefore, exposed to real language. However, teachers reported and observations showed several needs that are to be contended in relation to the aforementioned tools and devices. It becomes necessary to verify the correct functioning of equipment like laptops, screens, internet access, and speed since many of these failed when teaching the lessons. Equipment failures may have negatively impacted the proper implementation of the lessons. It is required to examine and reduce these unfavorable circumstances in order to foster the progress of technology-oriented learning spaces.

Teachers' replies to the open-ended survey report a clear-cut benefit in relation to the use of songs and videos in the LP. Teachers valued the fact that these multimedia resources were concise and entertaining, related to the topics, and let children interact with thelanguage. They also furthered children's involvement, attention, and enjoyment. As Han, Leong, and Nair (2014) affirmed, interactive classroom technologies serve as a vehicle to involve students and to upgrade the quality of learning.

On the other hand, teachers experienced several complications when teaching the lessons. Firstly, the estimated times were not sufficient to complete several tasks in the LP and to prepare the logistics behind the lesson. Furthermore, some teachers found no available material in the resource center of the institution. In addition, several teachers commented that children had certain degree of anxiety when visiting the collaborative classroom and when not using the textbook along the class session. Herein, the class routine had been modified without announcing such fact in advanced. Saez (2010) suggested that external factors like no organized planning or presentation of tasks can have an impact on collaborative learning and may possibly influence the learning process. It is, then, crucial to explain children that not following the textbook becomes an opportunity to connect themselves to the everyday use of language, and teaching a lesson in a space different from the traditional room facilitates interaction with each other.

With respect to modifying stages in the LP, teachers said that the collaborative rooms should only be for small groups, having a maximum of twelve (12) students. The amount of participants can influence the accomplishment of collaboration, which is why a smaller group size can be beneficial to achieve cooperation among children (Dishon \& O'Leary, 1998). Another factor that teachers considered for adjustment is the amount of time projected for each activity. It is thus necessary to provide more time for the development of different tasks. Teachers also pointed out the fact of including more content in the lessons and omitting children's visiting neighbor classrooms to display work. It was shown, however, that children had a pleasing time taking part in 
the activities offered in the LP and they were able to soften the impact of sharing with people different from the ones they always meet in their rooms.

In addition to the use of Web 2.0 tools, videos, songs, and devices as laptops and T.V. screens, traditional resources like worksheets, photocopies, flashcards, magazine pictures, little boxes, colored sheets of paper, and a variety of classroom supplies were included in the LP. This kind of resources allowed children to engage in kinesthetic activities, to experience with trial and error, and, most importantly, to interact and discuss with their classmates while working in order to solve doubts and come to an agreement. Most teachers in the present study believed that the materials promoted enthusiasm, enhanced collaboration, and were appropriate to the population age and the lesson needs. Nonetheless, they complaint about the availability of some of the material in the resource center of the institution. Thus, the stock of supplies needs to be verified so that the lessons can be carried out as indicated. 


\section{Conclusions}

Based on the results of this study, we can conclude that children can effectively work in collaboration and that they enjoyed working towards a similar goal. It is obviously necessary to teach children how to collaborate with each other to avoid misbehaviors; they need to understand the rules and patterns of collaboration in order to effectively work together. Therefore, as part of lesson planning, it would be important to include a session where children are explained, in simple words, the principles of collaboration and how this non-traditional way of learning is beneficial to them. Teachers, as well, need to participate in educational courses where they learn about the theory and practices of collaborative learning in second language teaching.

In general, teachers think that the lessons fostered collaboration given the fact that the activities were suitable for students working well together and promoted student discussion and decision-making. As pointed out by different authors, collaborative learning oriented to younger students can encourage intellectual progress (Azmitia, 2000; Clark et al., 2003; Howe \& Tolmie, 1998). It also helps children to develop their knowledge, language, social skills, comprehension of new ideas, and planning to achieve a common goal or to solve a problem (Tunnard \& Sharp, 2009).

Considering some difficulties encountered by teachers when applying the lesson plans, it is necessary to adjust the timing proposed for certain activities and to some materials. In addition, computers and desks need to be in optimal conditions to guarantee the well-functioning of the lessons. The capacity of the rooms, as well, is a decisive element to the success of collaborative work. The small collaborative spaces in which this study was conducted are appropriate for no more than 9 children (three children at each table). This number of students allows for more interaction in small groups and collaborating effectively. Finally, the small collaborative room should be available only for children ages 10 an up. The rolling chairs may present a risk for smaller children. All of these aspects are fundamental as they lead to a more engaging learning environment for children.

The present study provided useful information for the use and design of collaborative lesson plans. It is important, however, to consider the lack of generalizability of our results. The sample size was rather small; therefore, caution must be exerted when interpreting the findings. Nonetheless, we provide important information that can be used in a larger scale study.

Pedagogical implications and further research on the importance of planning for collaborative learning are needed. Future researchers should focus on the impact this planning may have on the different students' age range, how it could be implemented in different socio-economic contexts and include other stakeholders of the institutions. New studies should include the students' voices and even be the basis for the creation of teachers' training programs. 


\section{References}

Azmitia, M. (2000). Taking time out from collaboration: opportunities for synthesis and emotion regulation. In R. Joiner, K. Littleton, D. Faulkner, \& D. Miell (Eds.), Rethinking collaborative learning (pp. 179-195). Free Association Books.

Barkley, E.F., Major, C.H., \& Cross, K.P. (2014). Collaborative Learning Techniques: A handbook for college faculty. (2nd ed.). Jossey-Bass.

Bawa, N., \& Suleiman, Z. (2015). Constructivism and classroom interaction. International Journal of Modern Social Sciences, 4(2), 71-81.

Brown, M., \& Long, P. (2006). Trends in learning space design. In D.G. Oblinger (Ed.), Learning Spaces (Ch 9). An Educause e-book. https://www. educause.edu/ir/library/pdf/pub7102.Pdf

Burr, V. (2003). Social constructionism. (2nd edition). Routledge.

Clark, A., Anderson, R.C., Kuo, L., Kim, I., Archodidou, A., \& NguyenJahiel, K. (2003). Collaborative reasoning: expanding ways for children to talk and think in school. Educational Psychology Review, 15, 181-198.

Collazos, C., Guerrero, L., \& Vergara, A. (2001) Aprendizaje Colaborativo: un cambio en el rol del profesor. https://www.researchgate.net/profile/Cesar_Collazos

Dillenbourg, P. (1999). What do you mean by collaborative learning? In P. Dillenbourg (Ed.) Collaborative-learning: Cognitive and Computational Approaches (pp.1-19). Elsevier. https://telearn.archives-ouvertes.fr/hal-00190240/ document

Dishon, D., \& O'Leary, P.W. (1998). Guidebook for cooperative learning: Techniques for creating more effective schools (3rd ed.). Learning Publications.

Doise, W., \& Mugny, G. (1984). The social development of the intellect. Pergamon.

Domalewska, D. (2014). Technology-supported classroom for collaborative learning: Blogging in the foreign language classroom. International Journal of Education and Development using Information and Communication Technology, 10(4), 21-30.

Dos Santos Lima, M. (2011). Collaborative tasks and learning occasions in English as a foreign language. Revista Brasileira de Lingüística Aplicada, 11(4), 837-852.

Gerlach, J.M. (1994). Is This Collaboration? In K. Bosworth, \& S.J. Hamilton (Eds.), Collaborative Learning: Underlying Processes and Effective Techniques (pp. 5-14). Jossey-Bass 
Gjergo E., \& Samarxhiu, S. (2011). Basic principles of collaborative learning. European Scientific Journal, 17, 22-36. http://eujournal.org/index.php/esj/issue/view/12

Gokhale, A.A. (1995). Collaborative Learning Enhances Critical Thinking. Journal of Technology Education, 7(1), 22-80. http://citeseerx.ist.psu.edu/viewdoc/ download?doi=10.1.1.77.1338\&rep $=$ rep $1 \&$ type $=$ pdf $\#$ page $=23$

Gremmen, M., van den Berg, Y.H., Segers, E., \& Cillessen, A.H. (2016). Considerations for classroom seating arrangements and the role of teacher characteristics and beliefs. Social Psychology of Education, 19(4), 749-774. https://www.researchgate. net/publication/311363766_Considerations_for_classroom_seating_ arrangements_and_the_role_of_teacher_characteristics_and_beliefs

Hafner, C.A., \& Miller, L. (2011). Fostering learner autonomy in English for science: A collaborative digital video project in a technological learning. Language Learning \& Technology, 15(3), 68-86. http://citeseerx.ist.psu.edu/viewdoc/ download?doi=10.1.1.471.4705\&rep=rep1\&type $=$ pdf

Han, A.N., Leong, L. C., \& Nair, K.P. (2014). X-Space Model: Taylor's University's Collaborative Classroom Design and Process. Procedia - Social and Behavioral Sciences, 123, 272-279. https://ac.els-cdn.com/S1877042814014621/1-s2.0S1877042814014621-main.pdf?_tid=aef64a73-28ca-4e5b-8297-f2a80c09ad54\&ac dnat $=1541024005 \_11884834 c 25515 \mathrm{e} 45876796 \mathrm{~d} 949 \mathrm{bcdcb}$

Harmer, J. (2007). How to teach English. Pearson Education Limited.

Holm, R. (2018). A collaborative teaching material package for EFL teaching in grades 7-9 [Master's Thesis]. https://jyx.jyu.fi/bitstream/handle/123456789/57135/1/ URN\%3ANBN\%3Afi\%3Ajyu-201802211544.pdf

Howe, C.J., \& Tolmie, A. (1998). Productive interaction in the context of computersupported collaborative learning in science. In K. Littleton, \& P. Light (Eds.), Learning with computers: Analyzing productive interaction (pp. 24-45). Routledge.

Jacobs, G. M., Power, M. A., Loh, W. I. (2002). The teacher's sourcebook for cooperative learning: Practical techniques, basic principles, and frequently asked questions. Corwin Press.

Larrañaga, N.I. (2012). The impact of contextual factors in the development of collaborative writing in CLIL-POL settings at tertiary level [Doctoral dissertation]. https://katalogoa.mondragon.edu/Documentos/Libros/HUHEZI/Liburu_Irekiak/ NagoreIpi\%C3\%B1a_Liburua_2012-2013.pdf 
Le, H., Janssen J., \& Wubbels, T. (2018). Collaborative learning practices: teacher and student perceived obstacles to effective student collaboration. Cambridge Journal of Education, 48(1), 103-122. https://doi.org/10.1080/0305764X.2016.1259389

Marshall, C. and Rossman, G. (2016). Designing Qualitative Research. (6th ed.). Sage Publications.

Meyers, M. D. (2004). Qualitative research in information systems. MIS Quarterly, $21,241-242$.

McCorskey, J.C., \& McVetta, R.W. (1978). Classroom seating arrangements: Instructional communication theory versus student preferences. Communication Education, 27, 99-111.

McInnerney, J.M., \& Roberts, T.S. (2003). Collaborative or Cooperative Learning? In T.S. Roberts (Ed.), Online collaborative learning: Theory and practice (pp. 203-214). Information Science Publishing.

Muukkonen, H., Lakkala, M., \& Hakkarainen, K. (2005). Technology-mediation and tutoring: How do they shape progressive inquiry discourse? Journal of the Learning Sciences, 14(4), 527-565.

Nilsson, B. (2016, January 11). What's a Collaborative Classroom and Why is It Important? Extreme. https://www.extremenetworks.com/extreme-networks-blog/ whats-a-collaborative-classroom-and-why-is-it-important/

Piaget, J. (1932). The moral development of the child. London: Routledge \& Kegan Paul.

Piaget, J. (1985). The equilibration of cognitive structures. University of Chicago Press.

Primary Professional Development Service (n.d.). Promoting group work, collaborative and cooperative learning in the primary school Tip sheet for teachers. http://www. pdst.ie/sites/default/files/Session\%203\%20-\%20PS\%20Co\%20-\%20Op\%20 \%EF\%80\%A2\%20Group\%20Work.pdf

Saéz, C.G. (2010). Consideraciones en la implementación de aprendizaje colaborativo en el aula con apoyo de tecnología de la información y la comunicación. Intersecciones educativas, 2, 43-52. http://educacion.ulagos.cl/revista/index.php/ edicion-ii/item/6-edicion2-articulo-4

Santamaria, F. (2005). Herramientas colaborativas para la enseñanza usando

Smith, B.L., \& MacGregor, J.T. (1992). What is collaborative learning? In A. S. Goodsell, M.R. Maher, \& V. Tinto (Eds.), Collaborative Learning: A Sourcebook for Higher Education (pp. 10-29). University Park, PA: National Center on Postsecondary Teaching, Learning, and Assessment. 
Song, J. (2011). An Application of Collaborative Learning in a CALL Website Construction. Theory and Practice in Language Studies, 1(1), 115-118. http://www. academypublication.com/issues/past/tpls/vol01/01/20.pdf

Swain, M. (2000). The output hypothesis and beyond: mediating acquisition through collaborative dialogue. In J. Lantolf (Ed.), Sociocultural theory and second language learning (pp. 97-114). Oxford University Press.

tecnologias web: weblogs, wikis, redes sociales y web 2.0. http://www.fernandosantamaria. com/descargas/herramientas_colaborativas2.pdf

The stationery office of Dublin (1999) Primary School Curriculum. https://www. curriculumonline.ie/getmedia/c4a88a62-7818-4bb2-bb18-4c4ad37bc255/ PSEC_Introduction-to-Primary-Curriculum_Eng.pdfRubin, J.H., \& Rubin S.J. (1995). Qualitative Interviewing, the Art of Hearing Data. Sage Publications.

Tunnard, S., \& Sharp, J. (2009). Children's views of collaborative learning. Education, 37(2),159-164.

\section{Authors}

${ }^{\star}$ Daisy Catalina Carvajal-Ayala finished her MA in Teaching English as a Foreign Language from Universidad Internacional Iberoamericana (UNINI) in Arecibo, Puerto Rico. She holds a BA in Modern Languages Teaching from the University of Quindío. She is an English teacher at EAFIT university

ORCID: https://orcid.org/0000-0003-2114-329X

Ricardo Alonso Avendaño-Franco finished his MA in Teaching and Learning Foreign Languages from University of Antioquia. He holds a specialist degree in Education and a BA in Modern Languages Teaching. He is the academic coordinator of the English programs for Children and teenagers at EAFIT university and is a member of the research group of language teaching and learning from the same university.

ORCID: https://orcid.org/0000-0001-5884-0991

How to reference this article: Carvajal-Ayala, D. C., \& Avendaño-Franco, R. A. (2021). Implementing Lesson Plans for Collaborative Learning with Children in an EFL Context. GIST Education and Learning Research Journal, 22(1), 199-226. https://doi.org/10.26817/16925777.872 